\title{
Family Structure in Association with Alcohol Use Among Adolescents: A Systematic Review and Meta-analysis
}

\author{
Zahra Pourmovahed ${ }^{1}$, Seyed Saeed Mazloomy Mahmoodabad ${ }^{2}$, Seyed Mojtaba Yassini Ardekani ${ }^{3}$, \\ Hassan Zareei Mahmoodabadi ${ }^{4}$, Hossein Tavangar ${ }^{1}$, Mojtaba Kaviani ${ }^{5}$, Amin Salehi-Abargouei ii ${ }^{6}$, \\ Nour-Mohammad Bakhshani (iD ${ }^{7}$ and Shahab-Aldin Akbarian (iD) ${ }^{6, *}$ \\ ${ }^{1}$ Department of Nursing Education, Research Center for Nursing and Midwifery Care, Shahid Sadoughi University of Medical Sciences, Yazd, IR Iran \\ ${ }^{2}$ Social Determinants of Health Research Center, Department of Health Education \& Promotion, School of Public Health, Shahid Sadoughi University of Medical Sciences, \\ Yazd, IR Iran \\ ${ }^{3}$ Department of Psychology, Research Center of Addiction and Behavioral Sciences, Shahid Sadoughi University of Medical Sciences, Yazd, IR Iran \\ ${ }^{4}$ Department of Education and Psychology, Yazd University, Yazd, IR Iran \\ ${ }^{5}$ Faculty of Pure \& Applied Science, School of Nutrition and Dietetics, Acadia University, Wolfville, Nova Scotia, Canada \\ ${ }^{6}$ Nutrition and Food Security Research Center, Department of Nutrition, School of Public Health, Shahid Sadoughi University of Medical Sciences, Yazd, IR Iran \\ ${ }^{7}$ Department of Clinical Psychology, Children and Adolescent Health Research Center, Zahedan University of Medical Sciences, Zahedan, IR Iran \\ "Corresponding author: Nutrition and Food Security Research Center, Department of Nutrition, School of Public Health, Shahid Sadoughi University of Medical Sciences, Yazd, \\ IR Iran. Email: shahaab.akbarian@gmail.com
}

Received 2021 January 23; Revised 2021 October 19; Accepted 2021 October 20.

\begin{abstract}
Context: It is proposed that family structure influences adolescent alcohol use; however, the findings are mixed, and no systematic review has been conducted to summarize the evidence.

Objectives: We aimed to identify the association between family structures and adolescent alcohol consumption through a systematic review and meta-analysis of observational studies.

Evidence Acquisition: PubMed, Scopus, and Google Scholar were searched until June 2017 for observational studies, which examined the relationship between family structure and adolescent alcohol use. A random-effects model was used to derive the overall odds ratio (OR) for the likelihood of alcohol use in different non-intact families compared with intact families (adolescents growing up with both biological parents).

Results: Fifty-seven articles met the eligibility criteria for the systematic review, and 29 were included in the meta-analysis. The meta-analysis revealed a significant increase in alcohol use among adolescents with non-intact families (OR $=1.27,95 \%$ confidence interval: 1.19, 1.36) compared with adolescents with intact families in which both biological parents were present. Living with one biological parent, living in a divorced family, loss of parents, and other types of the non-intact family also significantly increased the odds of alcohol use in adolescents $(\mathrm{P}<0.05)$.

Conclusions: All types of the non-intact family were linked to adolescents' alcohol use. The family structure could have an essential role in reducing high-risk behaviors, including alcohol use and its consequences in adolescents.
\end{abstract}

Keywords: Family Structure, Alcohol Abuse, Alcoholism, Adolescent, Systematic Review, Meta-analysis

\section{Context}

Adolescence is recognized as a critical and transitional period for developing adaptive behaviors (1). This period is characterized by rapid physical, psychological, cognitive, and sociocultural changes, coinciding with many threats to health, called risky behaviors (2). The risky behaviors might have harmful and lasting consequences during this period (3).

Adolescents' alcohol use is risky behavior that has become a public health issue. It is proposed that adolescents' alcohol consumption might be associated with other con- ditions, including mental health problems (such as emotional instability, depression, and suicide), risky sexual behaviors $(4,5)$, delinquency $(4,6)$, poor academic performance (7), maladaptive behavior, violence, accidents, and social exclusion $(7,8)$. Early alcohol use predicts future drinking patterns (9), contributing to long-term health consequences $(9,10)$. It is revealed that more than $70 \%$ of European students consumed alcohol at least once $(11,12)$. Almost half of all students drink alcohol by 13 years of age or before, while this proportion varies across countries (11, 13).

During adolescence, which can be considered a transi- 
tional period, families might support adolescents to adapt to social and emotional changes, including searching for identity, seeking independence, influencing by friends, and communicating (14). It is reported that adolescents whose parents were separated had poorer health and were more likely to smoke (14). Furthermore, lower health quality of life, particularly higher emotional and behavioral problems, might occur in non-nuclear family structures (15). In this regard, traditional nuclear families (intact families) in which both the biological father and mother are present appear to be better for this purpose $(16,17)$. It is also proposed that parental divorce has a persistent influence on adolescents, increasing the probability of alcohol use and drunkenness more than other elements such as poor socioeconomic position and low parental support $(18,19)$.

Recently, researchers have attempted to identify the influence of family processes on the patterns of alcohol use in adolescents. It would be necessary to identify the types of family structure and their relations to alcohol consumption $(18,20)$. However, studies have led to inconsistent results when examining the association between family structure and alcohol use in adolescents. For instance, it is revealed by some studies that adolescents living in broken families desire to use alcohol earlier and drink more hazardously $(21,22)$. It is also found that adolescents living with both biological parents were involved less repeatedly in high-risk behaviors, including alcohol consumption (23), than those living in other families with different structures. However, other studies have indicated no relationship between family structure and adolescent deviant behavior expressions $(24,25)$. Parental divorce is associated with a relative change in subjective well-being. The effect of divorce on subjective well-being is partially mediated by paternal absence (26). In contrast, family instability could lead to a broad spectrum of negative consequences, including poor economic status and behavioral problems in children (27).

\section{Objectives}

To the best of our knowledge, no systematic review has been published regarding the association between family structure and the likelihood of alcohol use by adolescents. Therefore, this study aimed to manage a systematic review and meta-analysis of observational studies and summarize the published evidence regarding the relationship between family structure and the likelihood of alcohol use among adolescents. Thus, this paper explores the effect of different family structures on alcohol consumption in adolescents to show how some factors may explain differences in alcohol drinking according to family type.

\section{Methods}

The current systematic review is reported based on PRISMA guidelines (http://www.prismastatement.org). The study protocol was also registered in the International Prospective Register of Systematic Reviews (http://www.crd.york.ac.uk/PROSPERO, registry code: CRD42017054484).

\subsection{Search Strategy}

We conducted a systematic search through published literature in Scopus, PubMed, and Google Scholar from 1986 up to 30 June 2017 to find relevant studies. The MeSH and non-MeSH keywords used for online search were "family structure", "single parents", "stepparents", "disengaged families", "engaged families", "enmeshed families", "under-organized families", "family communication", "undifferentiated families", "problem solving", "triangulation", "coalition", "parentified child", "life support", "family function", "family stability", "family support", "social support", "parent-child relationship", and "family roles" in combination with "alcoholism", "alcohol abuse", "alcohol drinking", "alcohol use", "alcohol consumption", "alcohol drinking patterns", "drunkenness", "alcohol drinking attitudes", and "alcohols", as well as "adolescent, "young adult", "adolescence", "teenager", "young people", "teen", "youth", "juvenile", and "adolescent health". No language or date restriction was used when searching the databases. Also, backward literature searching was done to identify references or works cited in the main articles in order to find more relevant papers.

\subsection{Inclusion Criteria}

Studies that mentioned family structures and any high-risk behavior in adolescents were selected to be further evaluated by reading their full texts. Adolescents were considered boys and girls between 11 and 25 years of age (28). In the next step, we selected the studies examining the association between any types of non-intact family structure and alcohol use in the adolescent population with cross-sectional and cohort designs, which reported odds ratios (OR) or risk ratios (RR). A non-intact family was defined as all kinds of family structure, except families where both biological parents were present. The different family structures and their definitions are summarized in Table 1. Alcohol use was also defined as the self-reported consumption of alcoholic beverages at least once a month (29). Studies were excluded if they investigated the association in other age groups.

All titles and abstracts were reviewed independently by two authors (ZP and ASA) to identify eligible studies. Two independent authors carefully checked the full texts 


\begin{tabular}{|c|c|c|}
\hline Family Structure & Definition & References \\
\hline $\begin{array}{l}\text { Intact (Two parents, Both parents, Both } \\
\text { biological parents, Bi-nuclear parent) }\end{array}$ & $\begin{array}{l}\text { Both biological parents are present, and adolescents } \\
\text { live together with their both biological parents in } \\
\text { one household. }\end{array}$ & $(22,30,31)$ \\
\hline Non-intact family & $\begin{array}{l}\text { Non-intact families included maternal, paternal, and } \\
\text { no-parent families. }\end{array}$ & (31) \\
\hline $\begin{array}{l}\text { Single parent (Separated single parent or } \\
\text { Divorced) }\end{array}$ & $\begin{array}{l}\text { The adolescents' parents did not live together } \\
\text { anymore due to parental divorce or separation. }\end{array}$ & \multirow{5}{*}{$(17,22,30,32)$} \\
\hline Single mother (mother only) & $\begin{array}{l}\text { Adolescents only live with their mothers. No } \\
\text { stepfather is present. }\end{array}$ & \\
\hline Single father (father only) & $\begin{array}{l}\text { Adolescents only live with their fathers. No } \\
\text { stepmother is present. }\end{array}$ & \\
\hline Mother and stepfather & $\begin{array}{l}\text { Adolescents live with their biological mother and } \\
\text { her new partner. }\end{array}$ & \\
\hline Father and stepmother & $\begin{array}{l}\text { Adolescents live with their biological father and his } \\
\text { new partner. }\end{array}$ & \\
\hline Loss of parents & $\begin{array}{l}\text { Neither natural parents were present because of } \\
\text { dying. }\end{array}$ & $(22)$ \\
\hline Other types of non-intact family & Neither natural parents were present. & $(30,32,33)$ \\
\hline \multicolumn{3}{|l|}{ Non-parent family home } \\
\hline \multicolumn{3}{|l|}{$\begin{array}{l}\text { Living with grandparents, aunts, uncles, } \\
\text { cousins, siblings }\end{array}$} \\
\hline Foster children & & \\
\hline
\end{tabular}

of the potentially relevant articles. Any discordances were resolved by discussion.

\subsection{Data Extraction}

The following information was extracted from the eligible studies: (1) first authors' family name; (2) publication year; (3) research location; (4) study design (cohort, cross-sectional); (5) sample size; (6) age and gender of participants; (7) types of family structure; and (8) odds ratios for the association between family structure and the likelihood of alcohol use in adolescents. All data were checked two times by ZP and ASA independently, and any disagreement in extracted data was resolved through discussion. The methodological quality was assessed using the Newcastle-Ottawa scale (Table 2) (34).

\subsection{Statistical Analysis}

The Odds Ratio (OR) and its 95\% Confidence Interval (95\% CI) for the likelihood of alcohol use in participants with any non-intact families compared with those with intact families (living with both biological parents) were recorded to calculate the log OR and standard error used as the effect size for meta-analysis. If the ORs were not reported, we calculated the effect sizes from the number of participants with and without alcohol use based on family structure categories. For studies that did not report the total number of participants without intact families, we used the number of participants reported for each type of non-intact family structure (father-only, mother-only, etc.). Then the calculated effect sizes were used to compare children with and without intact families in the overall analysis. DerSimonian and Liard's random-effects model was used to conduct the meta-analysis (58) because its hypothesis considers between-study variability. The heterogeneity was checked using Cochran's Q test and I-squared (I2) (58). Sensitivity analysis was performed by excluding each study from the overall meta-analysis. The publication bias was assessed by the visual inspection of funnel plots and conducting Egger's regression and Begg's adjusted rank correlation tests (59). All analyses were performed using STATA software, version 11.2 (Stata Corp, College Station, TX). The CIs that did not include one were considered significant at $\mathrm{P}<0.05$.

\section{Results}

\subsection{Search Result}

After the systematic search through all databases, 8,493 articles were identified. In the initial phase, 8,128 unrelated papers were excluded after reading titles/abstracts because they did not explore the association between family structure and high-risk behavior or alcohol use. In to- 


\begin{tabular}{|c|c|c|c|c|c|c|c|c|c|c|c|}
\hline Cohort Studies & & & & & & & & Outcom & & & Total Score, (9 Scores) \\
\hline \multicolumn{12}{|c|}{ Study } \\
\hline Shucksmith (1997) (29) & . & . & . & . & . & . & . & . & & . & 4 stars \\
\hline Blum 2000 (35) & . & . & . & . & . & . & . & . & & . & 5 stars \\
\hline Kendler $2002(36)$ & . & . & . & . & . & . & . & . & & . & 5 stars \\
\hline del Carmen 2002 (37) & . & . & . & : & : & . & * & . & & . & 8 stars \\
\hline Seljamo $2006(38)$ & - & . & . & . & . & . & . & . & & . & 8 stars \\
\hline Alati 2010 (39) & . & . & * & . & : & * & . & . & & * & 7 stars \\
\hline Jackson 2016 (40) & . & . & . & . & . & . & . & . & & . & 7 stars \\
\hline \multicolumn{12}{|c|}{ Cross-sectional studies } \\
\hline Miller 1997 (41) & . & . & . & * & $\cdot$ & . & . & & - & & 7 stars \\
\hline Hoffmann 2017(42) & . & . & . & $*$ & . & * & . & & . & & 8 stars \\
\hline Boyle 2001 (43) & . & . & . & . & . & . & . & & . & & 7 stars \\
\hline McArdle 2002 (44) & - & . & . & * & . & . & * & & . & & 7 stars \\
\hline Ledoux $2002(30)$ & - & . & . & $*$ & . & . & . & & . & & 7 stars \\
\hline Eitle 2005 (45) & . & . & . & $*$ & : & * & * & & . & & 8 stars \\
\hline Wagner 2008 (46) & . & . & . & . & . & . & . & & - & & 3 stars \\
\hline $\begin{array}{l}\text { Nikolakopoulos } 2008 \\
\text { (47) }\end{array}$ & . & . & . & . & . & . & . & & . & & o stars \\
\hline Choquet $2007(48)$ & . & . & . & $*$ & . & * & . & & - & & 8 stars \\
\hline Beebe 2008 (49) & & . & & * & · & . & . & & . & & 4 stars \\
\hline Wang 2009 (50) & . & . & . & $*$ & . & * & . & & - & & 8 stars \\
\hline Tomcikova 2009 (18) & . & * & * & $*$ & . & * & * & & - & & 9 stars \\
\hline Brassai $2009(51)$ & . & . & . & * & . & . & . & & . & & 6 stars \\
\hline Mak 2010(31) & $\cdot$ & * & * & $*$ & · & * & * & & - & & 9 stars \\
\hline Habib 2010 (52) & . & . & . & *. & . & . & .. & & . & & 10 stars \\
\hline Small 2014 (53) & $\cdot$ & * & * & * & . & * & * & & - & & 8 stars \\
\hline Rüütel 2014 (19) & . & . & . & $*$ & . & . & $*$ & & - & & 9 stars \\
\hline Huang 2015 (54) & - & * & * & * & $\cdot$ & * & * & & - & & 8 stars \\
\hline Tomcikova 2015 (55) & . & : & * & $*$ & . & . & $* *$ & & - & & 9 stars \\
\hline $\begin{array}{l}\text { Barfield-Cottledge } 2011 \\
(56)\end{array}$ & - & . & . & . & . & * & . & & . & & 6 stars \\
\hline Jacobs 2016 (57) & . & . & . & . & . & . & * & & . & & 6 stars \\
\hline
\end{tabular}

tal, 365 full texts were further checked to find the eligible articles. Most full-texts were excluded because the studies did not assess alcohol use. The flow chart of the study selection procedure is illustrated in Figure 1. Finally, 57 studies that evaluated the relationship between family structure and alcohol use in adolescents were included in this study, of which 29 studies had appropriate data for including in the meta-analysis, and 28 of them just appeared in the systematic review (Table 3). The definitions for alcohol use used by all of the studies included in the systematic review are summarized in Table 1 . Of 28 studies, 11 studies (17, 60-69) were not included in the meta-analysis because they reported mean \pm SD for the consumption of different alcoholic beverages, eight papers $(22,24,70-75)$ reported a linear association between various drinks and different family structures, and nine other studies $(33,39,76-82)$ did not report the required information for calculating the association between family structure and alcohol consumption in youth.

Among the reviewed articles included in the metaanalysis, 12 were conducted in the United States (35-37, 40, $42,45,46,49,50,53,56,57)$, two in France $(30,48)$, two in the UK $(41,44)$, two in Hong Kong $(31,54)$, two in Slovakia $(18,55)$, two in Australia $(39,52)$, and one in each of countries Canada (43), Greenland(19), Greece (47), Scotland(29), Romania (51), Sweden (84), and Finland (38) (Table 3). The participants' age ranged from 10 to 24 years. The studies' sample size ranged from 128 to 52,278 participants, and 279,012 individuals participated in all studies. The characteristics of studies used in the systematic review and metaanalysis are summarized in Table 3.

\subsection{Non-intact Versus Intact Family}

Our analysis of 28 studies revealed that the likelihood of alcohol consumption more than once per month was $27 \%$ higher among teenagers with non-intact families (OR 

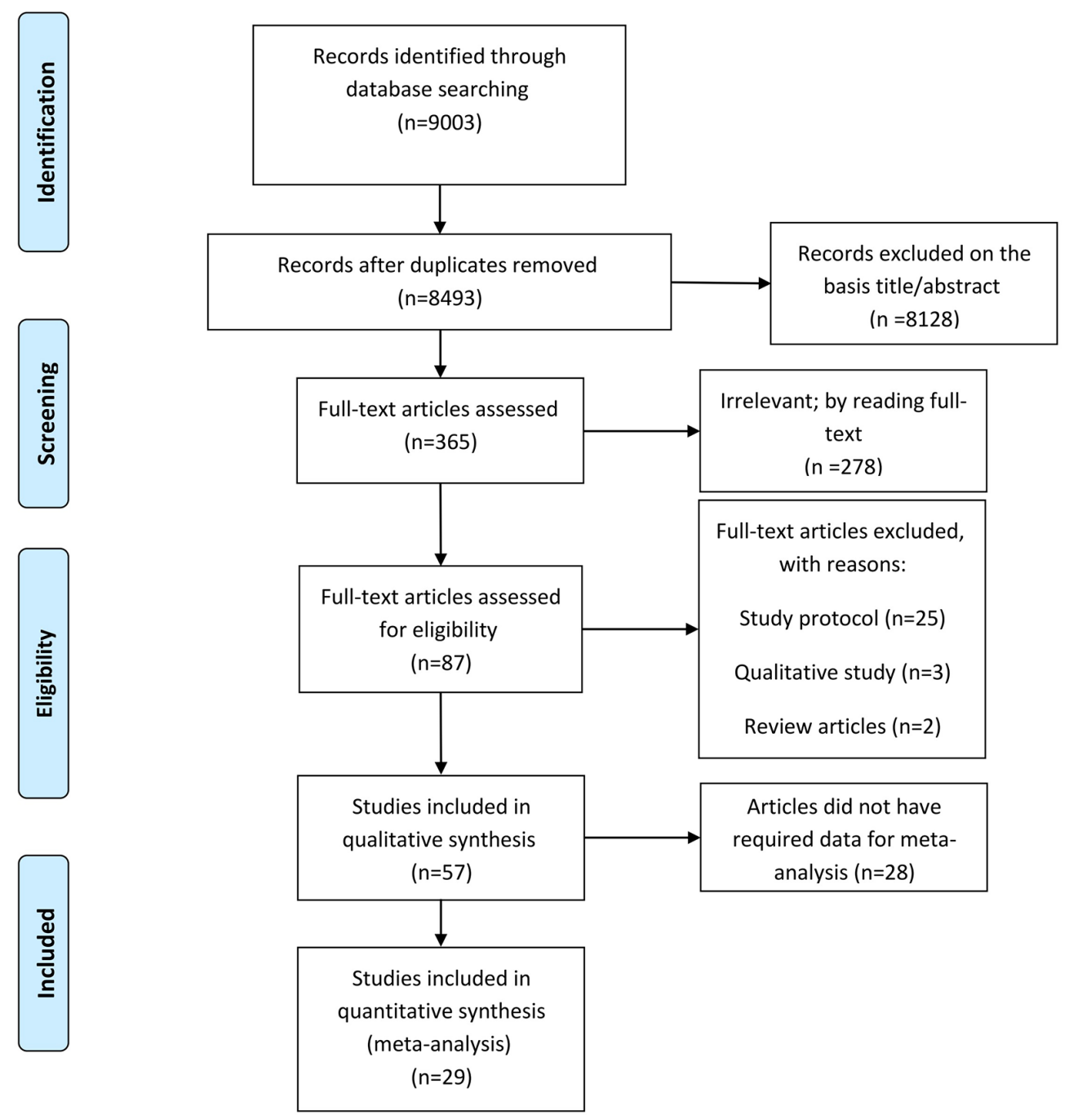

Figure 1. The study selection process diagram

$=1.27,95 \%$ confidence interval $(95 \% \mathrm{CI}): 1.19,1.36)$ compared to those with intact families (Figure 2). We recognized a significant heterogeneity (Cochran's $Q$ test, $Q$ statistic $=98.87$, $\mathrm{P}<0.001, \mathrm{I} 2=69.7 \%$ ) with no apparent reason to justify it. Therefore, we performed sensitivity analysis and divided non-intact families into different subgroups. The sensitivity analysis showed that none of the individual studies examining the association between non-intact families and the likelihood of alcohol use significantly changed the overall results. Although a slight asymmetry was seen in Begg's funnel plot, there was no evidence of publication bias in the selected studies assessing the effect of nonintact family on alcohol use (Begg's test, $\mathrm{Z}$ value $=0.01, \mathrm{P}$ $=0.919$; Egger's test, coefficient $=0.076, P=0.903$ ).

\subsection{Single-Parent Versus Intact Family}

The analysis of eight articles showed that alcohol use was more likely in adolescents living with single parents than those living with both biological parents ( $\mathrm{OR}=1.27$, 95\% CI: 1.17, 1.41). However, there was significant heterogeneity between studies (Cochran's $\mathrm{Q}$ test, $\mathrm{Q}$ statistic $=$ 53.06, $\mathrm{P}<0.001, \mathrm{I} 2=73.6 \%$ ) (Figure 3 ). No evidence of publication bias was observed in the studies included in the meta-analysis (Begg's test, $\mathrm{Z}$ value $=0.59, \mathrm{P}=0.553$; Egger's test, Coefficient $=0.65, \mathrm{P}=0.498$ ).

\subsection{Father-Only Versus Intact Families}

The evidence indicated that living only with a father increased the odds of drinking alcohol $(\mathrm{OR}=1.35,95 \% \mathrm{CI}$ : 


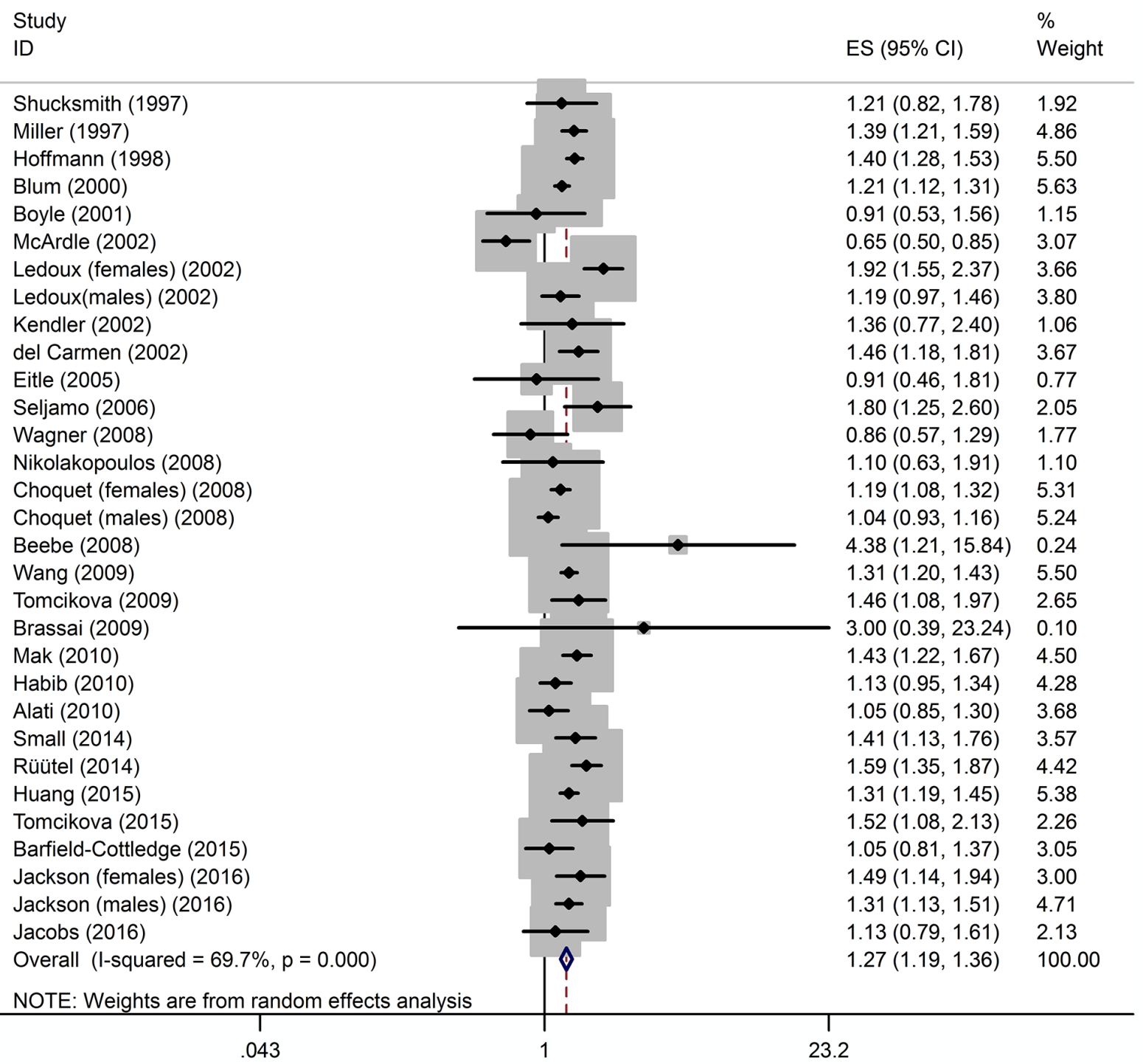

Figure 2. Forest plot illustrating weighted odds ratios of alcohol use in adolescents with non-intact families compared to those with intact families.

1.13, 1.60), but there was significant heterogeneity between studies (Cochran's Q test, Q statistic $=17.87, \mathrm{P}=0.02, \mathrm{I} 2=$ $55.2 \%$ ). The sensitivity analysis showed the main finding did not change by removing each study one by one. Although a slight asymmetry was seen in Begg's funnel plots, there was no evidence of publication bias using statistical tests (Begg's test, $\mathrm{Z}$ value $=0.52, \mathrm{P}=0.602$; Egger's test, $\mathrm{Co}-$ efficient $=-1.07, \mathrm{P}=0.375$ ).

\subsection{Mother-Only Versus Intact Family}

The finding from this meta-analysis showed that living only with mother also increased the chance of alcohol con- sumption in adolescents ( $\mathrm{OR}=1.25,95 \% \mathrm{CI}: 1.16,1.34)$, and the variability in the effect size due to heterogeneity was low (Cochran's Q test, $\mathrm{Q}$ statistic $=11.33, \mathrm{P}=0.184$, $\mathrm{I} 2=29.4 \%$ ). The sensitivity analysis showed that none of the individual studies examined the mentioned association. Even though there was a slight asymmetry in Begg's funnel plots, no evidence of publication bias was seen using asymmetry tests (Begg's test, $\mathrm{Z}$ value $=1.05, \mathrm{P}=0.295$; Egger's test, Coefficient $=1.28, \mathrm{P}=0.181$ ). 


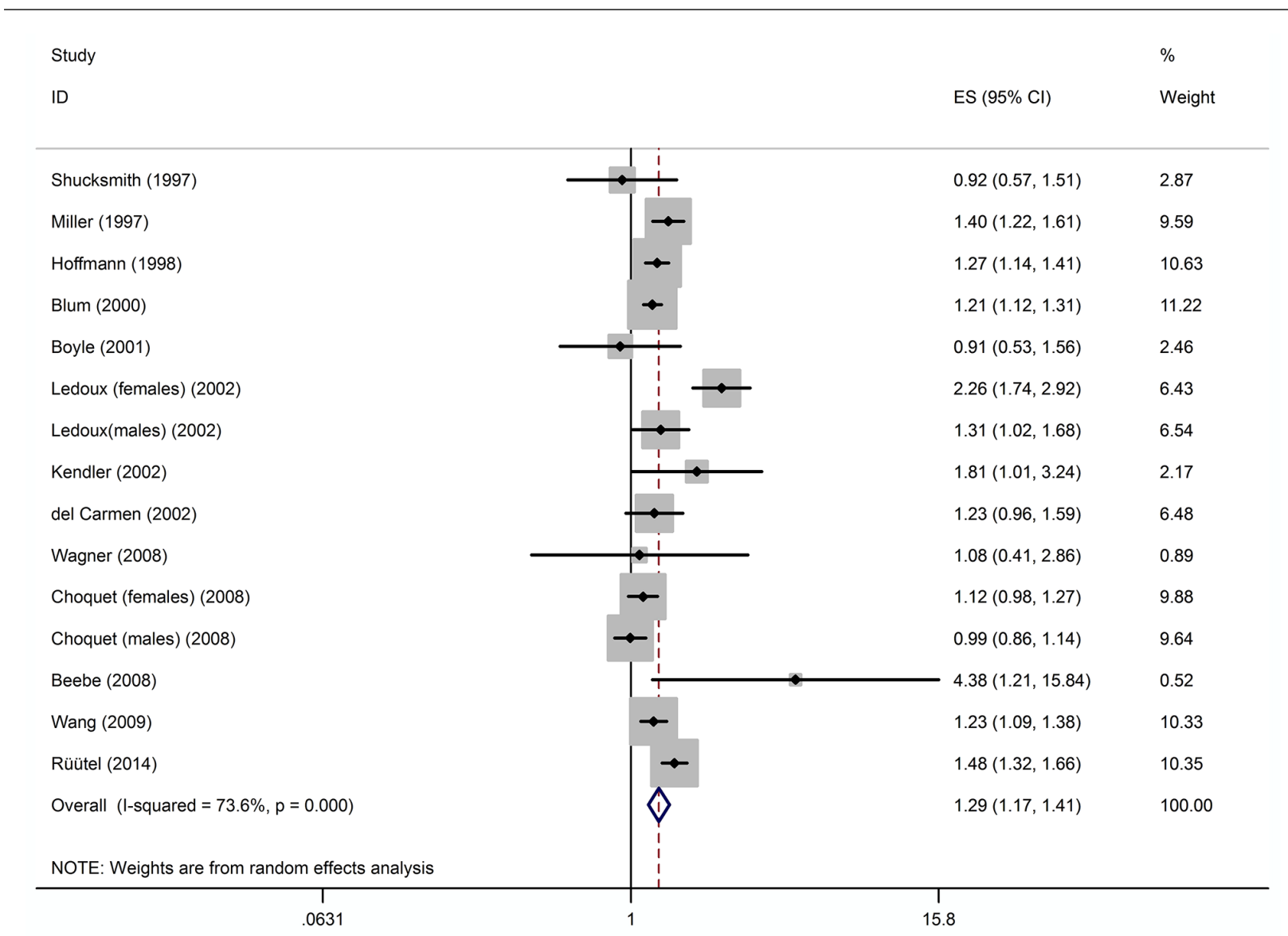

Figure 3. Forest plot illustrating weighted odds ratios of alcohol use in adolescents living in single-parent families compared to those with intact families.

\subsection{Divorced Versus Intact Family}

Six articles reported an association between living with divorced parents and alcohol consumption in adolescents $(18,36,39,40,50,54)$. This meta-analysis suggested an increased likelihood of alcohol use among young people (OR $=1.31,95 \%$ CI: $1.28,1.39$ ) while there was no significant heterogeneity between the results of articles (Cochran's Q test, $\mathrm{Q}$ statistic $=6.77, \mathrm{P}=0.34, \mathrm{I} 2=11.3 \%$, Figure 4$)$. The sensitivity analysis showed that none of the individual studies significantly affected overall results. Although a slight asymmetry was seen in Begg's funnel plots (supporting information Figure 4), there was no evidence of publication bias in the selected studies assessing the effect of divorced families on alcohol use (Begg's test, $\mathrm{Z}$ value $=0.90, \mathrm{P}=0.368$; Egger's test, Coefficient $=0.56, \mathrm{P}=0.546$ ).

\subsection{Parent-Absent Versus Intact Family}

The parental loss was defined as a disruption of the parent-child relationship through the age of 16 because of death or other causes (36). This meta-analysis showed a significant positive association (OR: 1.33, 95\% CI: 1.19, 1.48) between the loss of parents and the amount of alcohol drinking. No heterogeneity was shown in this subgroup (Cochran's Q test, Q statistic $=1.48, \mathrm{P}=0.688, \mathrm{I} 2=0.0 \%$ ). The sensitivity analysis showed no change in the overall result with the elimination of each study. No evidence of publication bias was found (Begg's test, $\mathrm{Z}$ value $=-0.34, \mathrm{P}=1.00$; Egger's test, Coefficient $=-0.37, \mathrm{P}=0.750)$.

\subsection{Stepparent Versus Intact Family}

Stepparent family was considered as living with one birth parent (either father or mother) and one stepparent (either stepfather or stepmother) (19). The meta-analysis showed that the existence of stepparents in the family might be related to the likelihood of alcohol consumption with the OR of 1.57 (95\% CI: 1.39, 1.77) while the heterogeneity was moderate (Cochran's Q test, $\mathrm{Q}$ statistic $=12.99, \mathrm{P}=$ $0.07, \mathrm{I} 2=46.1 \%$, Figure 5 ). The sensitivity analysis showed no important study. There was no evidence of publication 


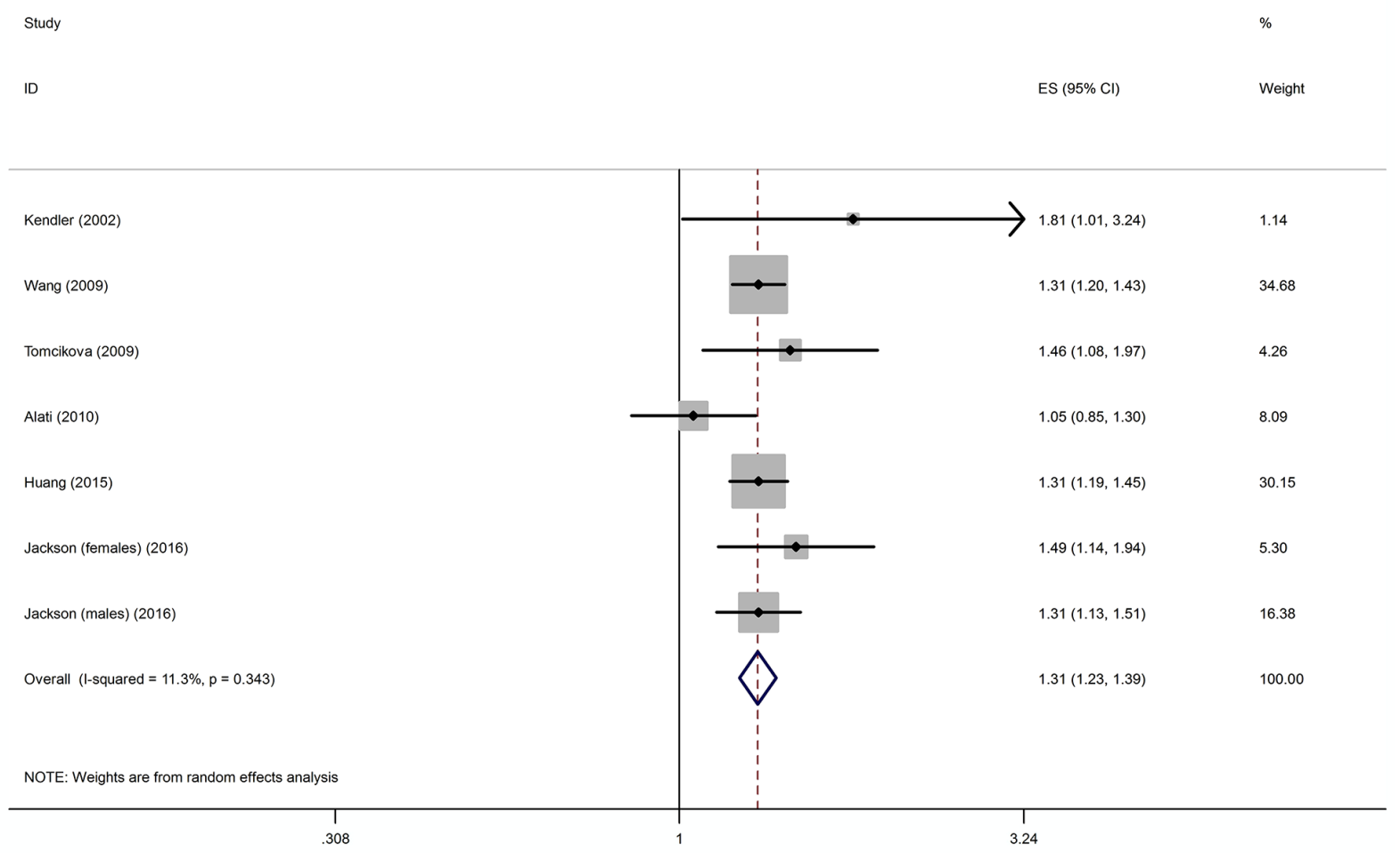

Figure 4. Forest plot illustrating weighted odds ratios of alcohol use in adolescents living in a family with divorced parents compared to those with intact families.

bias (Begg's test, $\mathrm{Z}$ value $=0.87, \mathrm{P}=0.386$; Egger's test, Coefficient $=0.391, \mathrm{P}=0.741)$.

\subsection{Other Types of Parental Family Versus Intact Family}

In this study, adolescents who had other categories of family structure, except for father-only, mother-only, divorced parents, parent-absent, and stepparent family structures, were considered to be in other types of parental families (in which none of the natural parents, including grandparents, aunts, uncles, cousins, siblings, and adopted children were present). This meta-analysis showed a significant positive association between these family structures and alcohol use (OR $=1.42,95 \% \mathrm{CI}$ : 1.15 , 1.76). There was heterogeneity between studies reporting the association between other parental families and alcohol abuse (Cochran's Q test, $\mathrm{Q}$ statistic $=17.80, \mathrm{P}=<0.001$, I2 $=77.5 \%$ ). The sensitivity analysis showed no effective study on the overall result after its deletion. Although a slight asymmetry was seen in Begg's funnel plots, there was no evidence of publication bias in the selected studies assessing the effect of other types of the parental family on alcohol use (Begg's test, $\mathrm{Z}$ value $=0.73, \mathrm{P}=0.462$; Egger's test, Coefficient $=-1.44, \mathrm{P}=0.601)$.

\section{Discussion}

The present study assessed the association between family structure and alcohol use among adolescents. The analyses revealed that growing up in a non-intact family was associated with adolescent alcohol use. To the best of our knowledge, this is the first systematic review and metaanalysis on this subject. For centuries, alcohol consumption has been part of culture and society. Drinking alcohol is a social activity embedded today in traditional and sociocultural contexts (85).

Our results showed that most adolescents in emotionally broken families experienced parental fighting and domestic violence. The results also highlighted that the presence of a stepparent and substance use in the family was seen to be common family factors that may act as predictors of antisocial behavior among adolescents (86).

The previous studies reported that adolescents from non-intact families were more likely to be weekly drinkers (31). Still, Habib et al. stated that family structure might not predict alcohol use in adolescents (52). Living in families with two biological parents is a factor that protects against alcohol use in adolescence. In contrast, adolescents from single-parent families attempt to drink more 


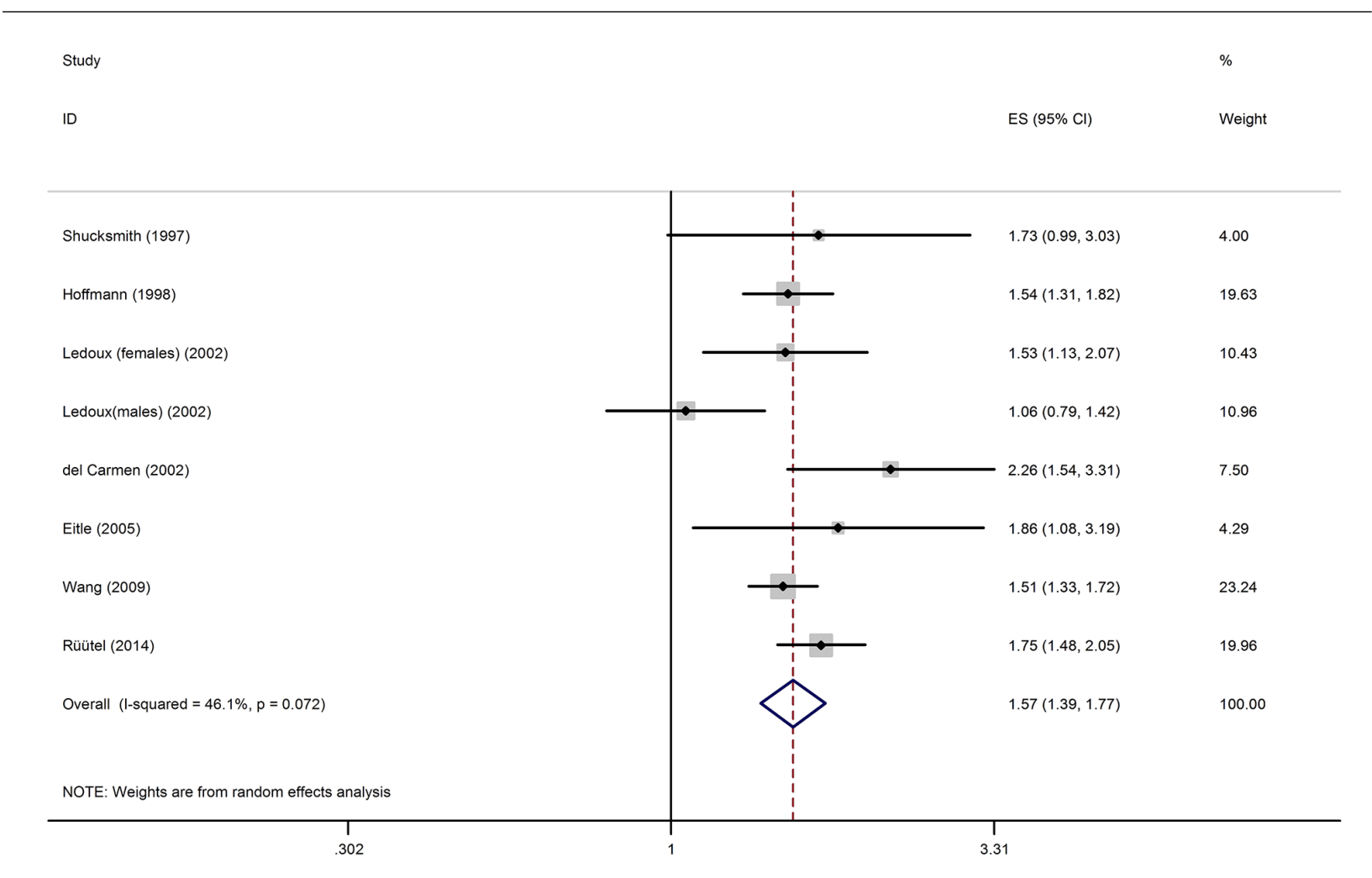

Figure 5. Forest plot illustrating weighted odds ratios of alcohol use in adolescents living with stepparents compared to those with intact families.

than adolescents from both-parent families (87). This statement is valid for the frequentness of alcohol use, the number of drinks on a routine day of drinking, and also the frequentness of excessive consumption $(19,88,89)$. However, the findings from some studies showed that there was no significant association between alcohol use and the existence of only one parent at home $(29,37,43,46,48)$.

Considering the growing number of adolescents living in single-parent families, we should continue considering the relationship between alcohol consumption and family structure (83). There are trends to offer that adolescents in single-father families might be at a higher chance of alcohol consumption and drunkenness than the others (84). This finding was also shown in the present study. However, it should be noted that we did not compare father-only families with mother-only families. In addition, parental divorce/separation has been shown to raise the later risk of alcohol dependence and difficulties among adolescents; however, its effect on the early phases of alcohol dependence has only recently been cleared (40). Sartor et al. (2007) noticed that parental separation predicted a younger age of first drink in children of a twins sample of young adults (90). Divorce provides a potent exam- ple, as alcoholic parents are at high risk of marital disintegration (91). It is, therefore, essential to keep in mind the moment at which the divorce occurs since it appears that older adolescents react by decreasing their relationship with the family and requesting support systems outdoors (92). Predisposing factors and resources shape families' responses to stressful events such as divorce. These may include finances, education, practical coping strategies, religiosity and spirituality, a history of successfully managing normative stressor events, cohesion, adaptability, and shared power. Unhealthy coping mechanisms like alcohol consumption in adolescents can also be considered (93).

In line with the result of our study, Huang et al. (2015) found that adolescents' current drinking status was associated with having one or both parents deceased (54). Kendler et al. reported that parental loss is a risk factor for alcohol dependence. They also found an increased risk of alcohol dependence after parental separation; however, the alcohol dependence was not increased after parents' death. Although the authors suggested that there was unlikely any direct causal link between the risk of alcohol dependence and separation, it may be interceded by indirect factors pointed to family disorganization and genetic fac- 
tors (36).

Several lines of evidence suggest that alcohol consumption was significantly lower in adolescents who lived in a family with both birth parents than in adolescents living in a family with biological parents, single parents, or one birth parent and one stepparent $(19,94)$. Further, it was reported that adolescents had higher drinking quantities in single-parent and stepparent families than in both birth-parents families. It was concluded that living with biological parents is protective against alcohol drinking in adolescence (19). Stepparent families might experience a significant alternation during the initial family disconnect, terminating a higher risk of drinking problems (94).

In the absence of one of the parents in the family, adolescents were to receive lower supervision during outside activities (95). Also, it is shown that poor supervision and monitoring by parents could propel adolescents forward to peers to meet their emotional needs (96). Furthermore, studies have demonstrated the influence of friends on drinking experiments and pleasure night outs (97), and some papers noticed that young people feel trust and safety in peer groups (98). In addition, the availability of alcohol at an early age increases in unstructured families (40). Family conflict is another mediator for increasing alcohol consumption, even though it is unclear whether this conflict occurs before the divorce or appears after (99). Therefore, these stressful conditions could lead to consuming alcohol more frequently (96).

Three studies $(50,53,83)$ showed a significant association between alcohol consumption and living in other types of family such as living with grandfathers or grandmothers, siblings, other relatives, foster homes, or someone else. It was shown that living with someone else other than a parent increased the odds of alcohol use (53). In addition, living in an extended family with other or nonfamily members was also a risk factor for alcohol use (68).

The present study was subject to several limitations. We were unable to investigate additional subgroups (e.g., different types of two-parent households in addition to stepparents: both biological parents vs. grandparents, other relatives, adoptive, foster, other adults, etc.). In addition, examining the effect of other moderators like age, sex, religion, and ethnic background that could explain the heterogeneity in the effect sizes would be worthwhile for future researchers in this area to pursue. It is worth mentioning that the extracted effect sizes were originated from crude analyses and were derived from studies with cross-sectional designs. Therefore, conducting large-scale prospective studies that consider the effect of modifiers in their analyses might better elucidate the association between family structure and alcohol use in future investigations. Also, Sandstrom (2013) stated that economic insta- bility might harm children by undermining their health (100). Working rules and sick leave often reduce poverty for families. Family benefit schemes may increase the risk of single-parent families in poverty over couple-parent families; however, the decomposition analyses show that family benefits help reduce poverty for all, especially singleparent families (101).

Given that living in single-parent households may be a risk factor for children's health, the public health-care system should provide additional social care for singleparent households. Further investigations are necessary using more detailed longitudinal data, including environmental and family factors and the severity of adolescents' health conditions to support our findings (102). It should also be noted that we could not include some investigations in this meta-analysis because of heterogeneity between study reports and missing data. In addition, only studies published in English were included in the review, which might have skewed the results. Further, we did not observe any evidence of publication bias based on funnel plots in the meta-analysis of included studies. Another limitation of the study is that the authors did not compare alcohol drinking behaviors across different age groups. Also, the frequency and drinking behavior of adolescents could not be assessed.

In addition, some studies varied in the definition of family structure and often overlapped conceptually, which could affect the analysis; however, we reduced this limitation by conducting subgroup analyses. Despite these limitations, the current review provides valuable results of the effects of the types of family structure on alcohol consumption in adolescents.

In summary, the published research demonstrates that living with both biological parents significantly reduces alcohol consumption in adolescents than living in other types of non-intact families such as a single-parent, fatheronly, mother-only, divorced-parent, parent-absent, stepparent, and other types of parental families. Family health and its stability could have an essential role in reducing high-risk behaviors, including alcohol use and its consequences in adolescents. Further investigation is required to assess familial, parental, and psychosocial protective factors within different family structures influencing adolescents' drinking.

\section{Footnotes}

Authors' Contribution: Study concept and design, Zahra Pourmovahed and Seyed Saied Mazloomy Mahmoodabad; Analysis and interpretation of data, Amin Salehi-Abargouei, Zahra Pourmovahed, and Shahab-Aldin 
Akbarian; Drafting of the manuscript, Shahab-Aldin Akbarian, Zahra Pourmovahed, and Mojtba Kaviani; Critical revision of the manuscript for important intellectual content, Seyed Mojtaba Yassini Ardekani, Hassan Zareei Mahmoodabadi, Hossein Tavangar, and Mohammad Bakhshani; Statistical analysis, Amin Salehi-Abargouei.

Conflict of Interests: There is no conflict of interest.

Funding/Support: Shahid Sadoughi University of Medical Sciences, Yazd, Iran, supported this study.

\section{References}

1. Steinberg L. Age of opportunity: Lessons from the new science of adolescence. Massachusetts, USA: Houghton Mifflin Harcourt; 2014.

2. Patton GC, Viner R. Pubertal transitions in health. Lancet. 2007;369(9567):1130-9. doi: 10.1016/S0140-6736(07)60366-3. [PubMed: 17398312].

3. Sychareun V, Thomsen S, Faxelid E. Concurrent multiple health risk behaviors among adolescents in Luangnamtha province, Lao PDR. BMC Public Health. 2011;11:36. doi: 10.1186/1471-2458-11-36. [PubMed: 21232108]. [PubMed Central: PMC3031220].

4. Cavazos-Rehg PA, Spitznagel EL, Bucholz KK, Nurnberger JJ, Edenberg HJ, Kramer JR, et al. Predictors of sexual debut at age 16 or younger. Arch Sex Behav. 2010;39(3):664-73. doi: 10.1007/s10508-0089397-y. [PubMed: 18846417]. [PubMed Central: PMC2855761].

5. Roerecke M, Rehm J. Irregular heavy drinking occasions and risk of ischemic heart disease: A systematic review and meta-analysis. Am J Epidemiol. 2010;171(6):633-44. doi: 10.1093/aje/kwp451. [PubMed: 20142394].

6. Peleg-Oren N, Saint-Jean G, Cardenas GA, Tammara H, Pierre C. Drinking alcohol before age 13 and negative outcomes in late adolescence. Alcohol Clin Exp Res. 2009;33(11):1966-72. doi: 10.1111/j.15300277.2009.01035.x. [PubMed: 19719795].

7. McCann M, Perra O, McLaughlin A, McCartan C, Higgins K. Assessing elements of a family approach to reduce adolescent drinking frequency: Parent-adolescent relationship, knowledge management and keeping secrets. Addiction. 2016;111(5):84353. doi: 10.1111/add.13258. [PubMed: 26638189]. [PubMed Central: PMC4949705].

8. Kaess M, Brunner R, Parzer P, Carli V, Apter A, Balazs JA, et al. Riskbehaviour screening for identifying adolescents with mental health problems in Europe. EurChild Adolesc Psychiatry. 2014;23(7):611-20. doi: 10.1007/s00787-013-0490-y. [PubMed: 24248753].

9. Irons DE, Iacono WG, McGue M. Tests of the effects of adolescent early alcohol exposures on adult outcomes. Addiction. 2015;110(2):26978. doi: 10.1111/add.12747. [PubMed: 25251778]. [PubMed Central: PMC4459504].

10. Probst C, Roerecke M, Behrendt S, Rehm J. Socioeconomic differences in alcohol-attributable mortality compared with all-cause mortality: A systematic review and meta-analysis. Int JEpidemiol.2014;43(4):131427. doi: 10.1093/ije/dyu043. [PubMed: 24618188]. [PubMed Central: PMC4258771].

11. Annunziata A, Vecchio R, Mariani A. Alcohol Warnings and Moderate Drinking Patterns among Italian University Students: An Exploratory Study. Nutrients. 2017;9(6). doi: 10.3390/nu9060628. [PubMed: 28629138]. [PubMed Central: PMC5490607].

12. Schindler AG, Tsutsui KT, Clark JJ. Chronic alcohol intake during adolescence, but not adulthood, promotes persistent deficits in risk-based decision making. Alcohol Clin Exp Res. 2014;38(6):16229. doi: 10.1111/acer.12404. [PubMed: 24689661]. [PubMed Central: PMC4047126].
13. Thrul J, Pabst A, Kraus L. The impact of school nonresponse on substance use prevalence estimates - Germany as a case study. Int J Drug Policy. 2016;27:164-72. doi: 10.1016/j.drugpo.2015.06.005. [PubMed: 26212023]. [PubMed Central: PMC4696918].

14. Archibald AB, Graber JA, Brooks-Gunn J. Pubertal Processes and Physiological Growth in Adolescence. In: Adams GR, Berzonsky MD, editors. Blackwell Handbook of Adolescence. New Jersey, USA: Blackwell Publishing Ltd; 2006. p. 24-47. doi: 10.1002/9780470756607.ch2.

15. Rattay P, von der Lippe E, Mauz E, Richter F, Holling H, Lange C, et al. Health and health risk behaviour of adolescents-Differences according to family structure. Results of the German KiGGS cohort study. PLoS One. 2018;13(3). e0192968. doi: 10.1371/journal.pone.0192968. [PubMed: 29513693]. [PubMed Central: PMC5841741].

16. Kreppner $\mathrm{K}$. The child and the family: Interdependence in developmental pathways. Psicol: Teor Pesqui. 2000;16(1):11-22. doi: 10.1590/s0102-37722000000100003.

17. Perez Milena A, Perez Milena R, Martinez Fernandez ML, Leal Helmling FJ, Mesa Gallardo I, Jimenez Pulido I. [Family structure and function during adolescence: Relationship with social support, tobacco, alcohol and drugs consumption, and psychic discomfort]. Aten Primaria. 2007;39(2):61-5. discussion 66-7. Spanish. doi:10.1157/13098670. [PubMed: 17306165]. [PubMed Central: PMC7664558].

18. Tomcikova Z, Madarasova Geckova A, Orosova O, van Dijk JP, Reijneveld SA. Parental divorce and adolescent drunkenness: role of socioeconomic position, psychological well-being and social support. Eur Addict Res. 2009;15(4):202-8. doi: 10.1159/000231883. [PubMed: 19657195].

19. Ruutel E, Sisask M, Varnik A, Varnik P, Carli V, Wasserman C, et al. Alcohol consumption patterns among adolescents are related to family structure and exposure to drunkenness within the family: Results from the SEYLE project. Int JEnviron Res Public Health. 2014;11(12):1270015. doi: 10.3390/ijerph111212700. [PubMed: 25493392]. [PubMed Central: PMC4276641].

20. Jacob T, Dunn NJ, Leonard K. Patterns of alcohol abuse and family stability. Alcohol Clin Exp Res. 1983;7(4):382-5. doi: 10.1111/j.15300277.1983.tb05489.x. [PubMed: 6362462].

21. Kirby JB. From Single-Parent Families to Stepfamilies. J Fam Issues. 2016;27(5):685-711. doi: 10.1177/0192513x05284855.

22. Vanassche S, Sodermans AK, Matthijs K, Swicegood G. The Effects of Family Type, Family Relationships and Parental Role Models on Delinquency and Alcohol Use Among Flemish Adolescents.J Child Fam Stud. 2013;23(1):128-43. doi: 10.1007/s10826-012-9699-5.

23. Demuth S, Brown SL. Family Structure, Family Processes, and Adolescent Delinquency: The Significance of Parental Absence Versus Parental Gender. J Res Crime Delinq. 2016;41(1):58-81. doi: 10.1177/0022427803256236.

24. Sokol-Katz JS, Ulbrich PM. Family structure and adolescent risk-taking behavior: A comparison of Mexican, Cuban, and Puerto Rican Americans. Int J Addict. 1992;27(10):1197-209. doi: 10.3109/10826089209047344. [PubMed: 1399160].

25. Velleman RD, Templeton LJ, Copello AG. The role of the family in preventing and intervening with substance use and misuse: A comprehensive review of family interventions, with a focus on young people. Drug Alcohol Rev. 2005;24(2):93-109. doi: 10.1080/09595230500167478. [PubMed: 16076580].

26. Storksen I, Roysamb E, Moum T, Tambs K. Adolescents with a childhood experience of parental divorce: A longitudinal study of mental health and adjustment. J Adolesc. 2005;28(6):725-39. doi: 10.1016/j.adolescence.2005.01.001. [PubMed: 16291507].

27. Pourmovahed Z, Mazloomy Mahmoodabad SS, Zareei Mahmoodabadi H, Tavangar H, Yassini Ardekani SM, Vaezi AA. Deficiency of SelfEfficacy in Problem-Solving as a Contributory Factor in Family Instability: A Qualitative Study. Iran J Psychiatry. 2018;13(1):32-9. [PubMed: 29892315]. [PubMed Central: PMC5994226].

28. Curtis AC. Defining adolescence. Journal of Adolescent and Family Health. 2015;7(2):2. 
29. Shucksmith J, Glendinning A, Hendry L. Adolescent drinking behaviour and the role of family life: A Scottish perspective. J Adolesc. 1997;20(1):85-101. doi: 10.1006/jado.1996.0066. [PubMed: 9063777].

30. Ledoux S, Miller P, Choquet M, Plant M. Family structure, parent-child relationships, and alcohol and other drug use among teenagers in France and the United Kingdom. Alcohol Alcohol.2002;37(1):52-60. doi: 10.1093/alcalc/37.1.52. [PubMed: 11825858].

31. Mak KK, Ho SY, Thomas GN, Schooling CM, McGhee SM, Lam TH. Family structure, parent-child conversation time and substance use among Chinese adolescents. BMC Public Health. 2010;10:503. doi: 10.1186/14712458-10-503. [PubMed: 20723230]. [PubMed Central: PMC2931477].

32. Mazzuco S, Meggiolaro S. Family Structures and Health Behaviour in Adolescents. Child Indic Res. 2013;7(1):155-75. doi: 10.1007/s12187-0139207-5.

33. Lonczak HS, Fernandez A, Austin L, Marlatt G, Donovan DM. Family structure and substance use among American Indian youth: A preliminary study. Fam Syst Health. 2007;25(1):10-22. doi: 10.1037/10917527.25.1.10

34. Stang A. Critical evaluation of the Newcastle-Ottawa scale for the assessment of the quality of nonrandomized studies in meta-analyses. Eur J Epidemiol. 2010;25(9):603-5. doi: 10.1007/s10654-010-9491-z. [PubMed: 20652370].

35. Blum RW, Beuhring T, Shew ML, Bearinger LH, Sieving RE, Resnick MD. The effects of race/ethnicity, income, and family structure on adolescent risk behaviors. Am J Public Health. 2000;90(12):1879-84. doi: 10.2105/ajph.90.12.1879. [PubMed: 11111260]. [PubMed Central: PMC1446419].

36. Kendler KS, Sheth K, Gardner CO, Prescott CA. Childhood parental loss and risk for first-onset of major depression and alcohol dependence: The time-decay of risk and sex differences. Psychol Med. 2002;32(7):1187-94. doi: 10.1017/s0033291702006219. [PubMed: 12420888].

37. del Carmen M, Alcon G, Pedersen JM, Maria A, Gonzalez C. Greenlandic family structure and communication with parents: influence on schoolchildren's drinking behaviour. Int J Circumpolar Health. 2002;61(4):319-31. doi: 10.3402/ijch.v61i4.18210. [PubMed:12546190].

38. Seljamo S, Aromaa M, Koivusilta L, Rautava P, Sourander A, Helenius $\mathrm{H}$, et al. Alcohol use in families: A 15-year prospective follow-up study. Addiction. 2006;101(7):984-92. doi: 10.1111/j.1360-0443.2006.01443.x. [PubMed: 16771890].

39. Alati R, Maloney E, Hutchinson DM, Najman JM, Mattick RP, Bor W, et al. Do maternal parenting practices predict problematic patterns of adolescent alcohol consumption? Addiction. 2010;105(5):872-80. doi: 10.1111/j.1360-0443.2009.02891.x. [PubMed: 20331556].

40. Jackson KM, Rogers ML, Sartor CE. Parental divorce and initiation of alcohol use in early adolescence. Psychol Addict Behav. 2016;30(4):45061. doi: 10.1037/adb0000164. [PubMed: 27322803]. [PubMed Central: PMC4916852].

41. Miller P. Family structure, personality, drinking, smoking and illicit drug use: A study of UK teenagers. Drug Alcohol Depend. 1997;45(12):121-9. doi:10.1016/s0376-8716(97)01345-8. [PubMed: 9179514].

42. Hoffmann JP. Family Structure and Adolescent Substance Use: An International Perspective. Subst Use Misuse. 2017;52(13):1667-83. doi: 10.1080/10826084.2017.1305413. [PubMed: 28605218].

43. Boyle MH, Sanford M, Szatmari P, Merikangas K, Offord DR. Familial influences on substance use by adolescents and young adults. Can J Public Health.2001;92(3):206-9. [PubMed:11496632]. [PubMed Central: PMC6980139].

44. McArdle P, Wiegersma A, Gilvarry E, Kolte B, McCarthy S, Fitzgerald $\mathrm{M}$, et al. European adolescent substance use: the roles of family structure, function and gender. Addiction. 2002;97(3):329-36. doi: 10.1046/j.1360-0443.2002.00066.x. [PubMed: 11964109].

45. Eitle D. The moderating effects of peer substance use on the family structure-adolescent substance use association: quantity versus quality of parenting. Addict Behav. 2005;30(5):963-80. doi: 10.1016/j.addbeh.2004.09.015. [PubMed: 15893092].
46. Wagner KD, Ritt-Olson A, Soto DW, Unger JB. Variation in family structure among urban adolescents and its effects on drug use. Subst Use Misuse. 2008;43(7):936-51. doi:10.1080/10826080701801550. [PubMed: 18570026]. [PubMed Central: PMC3794458].

47. Nikolakopoulos KM, Nikolakopoulou NM. Family structure and risk behaviors in Greek adolescents: a short report. Int J Adolesc Med Health. 2008;20(3):271-3. doi: 10.1515/ijamh.2008.20.3.271. [PubMed: 19097564].

48. Choquet M, Hassler C, Morin D, Falissard B, Chau N. Perceived parenting styles and tobacco, alcohol and cannabis use among French adolescents: Gender and family structure differentials. Alcohol Alcohol. 2008;43(1):73-80. doi:10.1093/alcalc/agm060. [PubMed: 17932077].

49. Beebe LA, Vesely SK, Oman RF, Tolma E, Aspy CB, Rodine S. Protective assets for non-use of alcohol, tobacco and other drugs among urban American Indian youth in Oklahoma. Matern Child Health J. 2008;12(Suppl 1):82-90. doi: 10.1007/s10995-008-0325-5. [PubMed: 18278544].

50. Wang J, Simons-Morton BG, Farhat T, Luk JW. Socio-demographic variability in adolescent substance use: Mediation by parents and peers. Prev Sci. 2009;10(4):387-96. doi: 10.1007/s11121-009-0141-1. [PubMed: 19582581]. [PubMed Central: PMC3128886].

51. Brassai L, Pikó B. The role of parent-adolescent connection in child welfare: A study of high school students in Transylvania, Romania. In: Quintero SJ, editor. Child welfare issues and perspectives. New York, USA: NOVA Science Publishers; 2009. p. 55-76.

52. Habib C, Santoro J, Kremer P, Toumbourou J, Leslie E, Williams J. The importance of family management, closeness with father and family structure in early adolescent alcohol use. Addiction. 2010;105(10):1750-8. doi: 10.1111/j.1360-0443.2010.03021.x. [PubMed: 20670349].

53. Small E, Suzuki R, Maleku A. The impact of family and parental education on adolescents' substance use: A study of U.S. high school seniors. Soc Work Public Health. 2014;29(6):594-605. doi: 10.1080/19371918.2014.893855. [PubMed: 25144700].

54. Huang R, Ho SY, Wang MP, Lo WS, Lam TH. Sociodemographic risk factors of alcohol drinking in Hong Kong adolescents. J Epidemiol Community Health. 2016;70(4):374-9. doi: 10.1136/jech-2015-206418. [PubMed: 26468510].

55. Tomcikova Z, Veselska ZD, Geckova AM, van DijkJP, Reijneveld SA. Adolescents' drinking and drunkenness more likely in one-parent families and due to poor communication with mother. Cent Eur J Public Health. 2015;23(1):54-8. doi: 10.21101/cejph.a3951. [PubMed: 26036099].

56. Barfield-Cottledge T. The Triangulation Effects of Family Structure and Attachment on Adolescent Substance Use. Crime Delinq. 2011;61(2):297-320. doi: 10.1177/0011128711420110.

57. Jacobs W, Barry AE, Xu L, Valente TW. Hispanic/Latino Adolescents' Alcohol Use: Influence of Family Structure, Perceived Peer Norms, and Family Members' Alcohol Use. Am J Health Educ. 2016;47(4):253-61. doi: 10.1080/19325037.2016.1179141. [PubMed: 28392883]. [PubMed Central: PMC5382927].

58. DerSimonian R, Laird N. Meta-analysis in clinical trials revisited. Contemp Clin Trials. 2015;45(Pt A):139-45. doi: 10.1016/j.cct.2015.09.002. [PubMed: 26343745]. [PubMed Central: PMC4639420].

59. Egger M, Davey-Smith G, Altman D. Systematic reviews in health care: Meta-analysis in context. New Jersey, USA: John Wiley \& Sons; 2008.

60. Burnside MA, Baer PE, McLaughlin RJ, Pokorny AD. Alcohol use by adolescents in disrupted families. Alcohol Clin Exp Res. 1986;10(3):274-8. doi: 10.1111/j.1530-0277.1986.tb05089.x. [PubMed: 3526950].

61. Barnes GM, Windle M. Family factors in adolescent alcohol and drug abuse. Pediatrician. 1987;14(1-2):13-8. [PubMed: 3615298].

62. Billingham RE, Post J, Gross WC. Parental divorce and the change in drinking behavior from high school to college. Psychol Rep.1993;72(3 Pt 2):1275-81. doi: 10.2466/pro.1993.72.3c.1275. [PubMed: 8337340].

63. Griffin KW, Botvin GJ, Scheier LM, Diaz T, Miller NL. Parenting practices as predictors of substance use, delinquency, and aggression 
among urban minority youth: moderating effects of family structure and gender.PsycholAddict Behav.2000;14(2):174-84. doi:10.1037||0893164x.14.2.174. [PubMed: 10860116]. [PubMed Central: PMC3962786].

64. Kuntsche EN, Silbereisen RK. Parental Closeness and Adolescent Substance Use in single and two-parent Families in Switzerland. Swiss J Psychol.2004;63(2):85-92. doi: 10.1024/1421-0185.63.2.85.

65. Kuntsche EN, Kuendig $\mathrm{H}$. What is worse? A hierarchy of familyrelated risk factors predicting alcohol use in adolescence. Subst Use Misuse. 2006;41(1):71-86. doi: 10.1080/10826080500368694. [PubMed: 16393737].

66. Hemovich V, Lac A, Crano WD. Understanding early-onset drug and alcohol outcomes among youth: The role of family structure, social factors, and interpersonal perceptions of use. Psychol Health Med. 2011;16(3):249-67. doi: 10.1080/13548506.2010.532560. [PubMed: 21491334]. [PubMed Central: PMC3088114].

67. Rocheleau GC, Swisher RR. Adolescent Work and Alcohol Use Revisited: Variations by Family Structure. J Res Adolesc. 2012;22(4):694-703. doi: 10.1111/j.1532-7795.2012.00815.x. [PubMed: 23162371]. [PubMed Central: PMC3499133].

68. Eitle TM, Johnson-Jennings M, Eitle DJ. Family Structure and Adolescent Alcohol Use Problems: Extending Popular Explanations to American Indians. Soc Sci Res. 2013;42(6):1467-79. doi: 10.1016/j.ssresearch.2013.06.007. [PubMed: 24014896]. [PubMed Central: PMC3761382].

69. Richmond-Rakerd LS, Slutske WS, Heath AC, Martin NG. Effects of sibship size and composition on younger brothers' and sisters' alcohol use initiation: findings from an Australian twin sample. Alcohol Clin Exp Res. 2013;37(6):1016-24. doi: 10.1111/acer.12052. [PubMed: 23278275]. [PubMed Central: PMC3631572].

70. Bjarnason T, Andersson B, Choquet M, Elekes Z, Morgan M, Rapinett G. Alcohol culture, family structure and adolescent alcohol use: multilevel modeling of frequency of heavy drinking among 15-16 year old students in 11 European countries. J Stud Alcohol. 2003;64(2):200-8. doi: 10.15288/jsa.2003.64.200. [PubMed: 12713193].

71. Bjarnason T, Thorlindsson T, Sigfusdottir ID, Welch MR. Familial and Religious Influences on Adolescent Alcohol Use: A Multi-Level Study of Students and School Communities. Soc Forces. 2005;84(1):375-90. doi: 10.1353/sof.2005.0088.

72. Crawford LA, Novak KB. Parent-Child Relations and Peer Associations as Mediators of the Family Structure-Substance Use Relationship. $J$ Fam Issues. 2007;29(2):155-84. doi: 10.1177/0192513x07304461.

73. Eitle D. Parental gender, single-parent families, and delinquency: Exploring the moderating influence of race/ethnicity. Soc Sci Res. 2006;35(3):727-48. doi: 10.1016/j.ssresearch.2005.06.003.

74. Jordan LC, Lewis ML. Paternal Relationship Quality as a Protective Factor: Preventing Alcohol Use Among African American Adolescents. J Black Psychol. 2016;31(2):152-71. doi: 10.1177/0095798405274881.

75. Levitt A, Cooper ML. Should Parents Allow Their Adolescent Children to Drink at Home? Family Factors as Predictors of Alcohol Involvement Trajectories Over 15 Years.J Stud Alcohol Drugs. 2015;76(5):661-70. doi: 10.15288/jsad.2015.76.661. [PubMed: 26402346]. [PubMed Central: PMC4714819].

76. Ellickson SL, Tucker JS, Klein DJ, McGuigan KA. Prospective risk factors for alcohol misuse in late adolescence. J Stud Alcohol. 2001;62(6):77382. doi: $10.15288 /$ jsa.2001.62.773. [PubMed: 11838914].

77. Miller P, Plant M. The family, peer influences and substance use: Findings from a study of UK teenagers. J Subst Use. 2009;8(1):19-26. doi: $10.1080 / 1465989021000067209$.

78. Oman RF, Vesely SK, Tolma E, Aspy CB, Rodine S, Marshall L. Does Family Structure Matter in the Relationships Between Youth Assets and Youth Alcohol, Drug and Tobacco Use? J Res Adolesc. 2007;17(4):74366. doi: 10.1111/j.1532-7795.2007.00545.x.

79. Paxton RJ, Valois RF, Drane J. Is there a Relationship between Family Structure and Substance Use among Public Middle School Students? J Child Fam Stud. 2006;16(5):593-605. doi: 10.1007/s10826-006-9109-y.

80. Kask K, Markina A, Podana Z. The Effect of Family Factors on In- tense Alcohol Use among European Adolescents: A Multilevel Analysis. Psychiatry J. 2013;2013:250215. doi: 10.1155/2013/250215. [PubMed: 24236275]. [PubMed Central: PMC3820088].

81. Ewing BA, Osilla KC, Pedersen ER, Hunter SB, Miles JN, D'Amico EJ. Longitudinal family effects on substance use among an at-risk adolescent sample. Addict Behav. 2015;41:185-91. doi: 10.1016/j.addbeh.2014.10.017. [PubMed: 25452064]. [PubMed Central: PMC4314308].

82. Sonmez MB, Cakir D, Cinar RK, Gorgulu Y, Vardar E. Substance Use and Parent Characteristics Among High School Students: Edirne Sample in Turkey. J Child Adolesc Subst Abuse. 2016;25(3):260-7. doi: 10.1080/1067828x.2015.1037516.

83. Hoffmann JP, Johnson RA. A National Portrait of Family Structure and Adolescent Drug Use. J Marriage Fam. 1998;60(3):633. doi: $10.2307 / 353534$.

84. Jablonska B, Lindberg L. Risk behaviours, victimisation and mental distress among adolescents in different family structures. Soc Psychiatry Psychiatr Epidemiol. 2007;42(8):656-63. doi: 10.1007/s00127-0070210-3. [PubMed: 17522746].

85. Sudhinaraset M, Wigglesworth C, Takeuchi DT. Social and Cultural Contexts of Alcohol Use: Influences in a Social-Ecological Framework. Alcohol Res. 2016;38(1):35-45. [PubMed: 27159810]. [PubMed Central: PMC4872611].

86. Paschall MJ. Exposure to violence and the onset of violent behavior and substance use among black male youth: An assessment of independent effects and psychosocial mediators. Virginia, USA: Society for Prevention Research; 1996.

87. Luoma I, Puura K, Tamminen T, Kaukonen P, Piha J, Rasanen E, et al. Emotional and behavioural symptoms in 8-9-year-old children in relation to family structure. Eur Child Adolesc Psychiatry. 1999;8 Suppl 4:29-40. doi: 10.1007/s007870050124. [PubMed: 10654131].

88. Bifulco A, Schimmenti A, Jacobs C, Bunn A, Rusu AC. Risk Factors and Psychological Outcomes of Bullying Victimization: A Communitybased Study. Child Indic Res. 2014;7(3):633-48. doi: 10.1007/s12187-0149236-8.

89. Rutter M, Kim-Cohen J, Maughan B. Continuities and discontinuities in psychopathology between childhood and adult life.J Child Psychol Psychiatry. 2006;47(3-4):276-95. doi: 10.1111/j.1469-7610.2006.01614.x. [PubMed: 16492260].

90. Sartor CE, Lynskey MT, Heath AC, Jacob T, True W. The role of childhood risk factors in initiation of alcohol use and progression to alcohol dependence. Addiction. 2007;102(2):216-25. doi: 10.1111/j.13600443.2006.01661.x. [PubMed: 17222275].

91. Waldron M, Grant JD, Bucholz KK, Lynskey MT, Slutske WS, Glowinski AL, et al. Parental separation and early substance involvement: Results from children of alcoholic and cannabis dependent twins. Drug Alcohol Depend. 2014;134:78-84. doi: 10.1016/j.drugalcdep.2013.09.010. [PubMed: 24120074]. [PubMed Central: PMC3908916].

92. Hoffmann JP. Investigating the age effects of family structure on adolescent Marijuana use. $J$ Youth Adolesc. 1994;23(2):215-35. doi: 10.1007/bfo1537446.

93. Berger R, Weiss T. The Posttraumatic Growth model: An expansion to the family system. Traumatology. 2009;15(1):63-74. doi: $10.1177 / 1534765608323499$.

94. Ram B, Hou F. Changes in Family Structure and Child Outcomes: Roles of Economic and Familial Resources. Policy Stud J. 2003;31(3):309-30. doi: 10.1111/1541-0072.00024.

95. Loukas A, Prelow HM. Externalizing and Internalizing Problems in Low-Income Latino Early Adolescents. J Early Adolesc. 2016;24(3):25073. doi: 10.1177/0272431604265675.

96. Barrett AE, Turner RJ. Family structure and substance use problems in adolescence and early adulthood: examining explanations for the relationship. Addiction. 2006;101(1):109-20. doi: 10.1111/j.13600443.2005.01296.x. [PubMed: 16393197].

97. Roberts M, Townshend T, Pappalepore I, Eldridge A, Mulyawan B. Local variations in youth drinking cultures. London, UK: University of West- 
minster; 2012. Contract No.: 185935923X.

98. MacArthur GJ, Jacob N, Pound P, Hickman M, Campbell R. Among friends: A qualitative exploration of the role of peers in young people's alcohol use using Bourdieu's concepts of habitus, field and capital. Sociol Health Illn. 2017;39(1):30-46. doi: 10.1111/1467-9566.12467. [PubMed: 27573161]. [PubMed Central: PMC5244664].

99. Kristjansson AL, Sigfusdottir ID, Allegrante JP, Helgason AR. Parental divorce and adolescent cigarette smoking and alcohol use: Assessing the importance of family conflict. Acta Paediatr. 2009;98(3):53742. doi:10.1111/j.1651-2227.2008.01133.x. [PubMed:19021591].
100. Sandstrom H, Huerta S. The Negtive effects of instability on child development: A research Sysnthesis. Washington, USA: The Urban Institute; 2013.

101. Maldonado LC. Doing Better for Single-Parent Families Poverty and Policy across 45 Countries [dissertation]. Los Angeles, USA: University of California; 2017.

102. Nishioka D, Saito J, Ueno K, Kondo N. Single-parenthood and health conditions among children receiving public assistance in Japan: Acohort study. BMC Pediatr. 2021;21(1):214. doi: 10.1186/s12887-021-02682-4. [PubMed: 33941113]. [PubMed Central: PMC8091550]. 
Pourmovahed Z et al.

Table 3. Characteristics of Eligible Cross-sectional and Cohort Studies Evaluating the Effect of Family Structure on Alcohol Consumption in Adolescents

\begin{tabular}{|c|c|c|c|c|c|c|c|}
\hline References & Country & $\begin{array}{l}\text { Study } \\
\text { Design }\end{array}$ & $\begin{array}{l}\text { No. of Par- } \\
\text { ticipants }\end{array}$ & Sex & Age Range & Family Structures Studied & $\begin{array}{l}\text { Results (Association Between Family Structure and Alcohol } \\
\text { Consumption) }\end{array}$ \\
\hline (60) & USA & $\begin{array}{c}\text { Cross- } \\
\text { sectional }\end{array}$ & 699 & Female & $12-17$ & $\begin{array}{l}\text { Both natural parents, a natural parent alone, } \\
\text { stepparent }\end{array}$ & No significant association was found \\
\hline (61) & USA & $\begin{array}{c}\text { Cross- } \\
\text { sectional }\end{array}$ & 673 & Both & $15-18$ & Both natural parents, single parent, stepparent & No significant association was found \\
\hline (24) & USA & $\begin{array}{c}\text { Cross- } \\
\text { sectional }\end{array}$ & 1237 & Both & $12 \cdot 18$ & Single parent, two-parent & $\begin{array}{l}\text { A significant association was found between alcohol use and } \\
\text { single-parent families among Mexicans. }\end{array}$ \\
\hline (62) & USA & $\begin{array}{c}\text { Cross- } \\
\text { sectional }\end{array}$ & 481 & Both & $17-23$ & Divorced, intact family & No significant association was found \\
\hline$(41)^{\mathbf{a}}$ & UK & $\begin{array}{c}\text { Cross- } \\
\text { sectional }\end{array}$ & 7722 & Both & $15-16$ & Both parents, mother, father, neither parents & $\begin{array}{l}\text { No significant association was found between alcohol use and } \\
\text { living with neither-parent or single-parent }\end{array}$ \\
\hline$(29)^{\mathbf{a}}$ & Scotland & Cohort & 627 & Both & $13-18$ & $\begin{array}{l}\text { One parent, reconstituted with stepparent, } \\
\text { two-parent }\end{array}$ & $\begin{array}{l}\text { A significant association was found between alcohol use and } \\
\text { living with an intact family. }\end{array}$ \\
\hline (83) & USA & $\begin{array}{c}\text { Cross- } \\
\text { sectional }\end{array}$ & 22230 & Both & $12-17$ & $\begin{array}{l}\text { Both parents, mother-father-other, } \\
\text { mother-stepfather, father-stepmother, mother } \\
\text { only, father only, mother-other relatives, other } \\
\text { relative-only, other family types }\end{array}$ & $\begin{array}{l}\text { A significant association was found between alcohol use and } \\
\text { living with father-stepmother, mother-only, and father-only }\end{array}$ \\
\hline (63) & USA & $\begin{array}{c}\text { Cross- } \\
\text { sectional }\end{array}$ & 228 & Both & 12 & $\begin{array}{l}\text { Two-parent, single-parent, mother-only, } \\
\text { father-only, households headed by guardians or } \\
\text { other relatives }\end{array}$ & $\begin{array}{l}\text { A significant association was found between alcohol use and } \\
\text { single-parent family (Gender } \times \text { Family Structure interactions } \\
\text { in boys) }\end{array}$ \\
\hline$(35)^{\mathbf{a}}$ & USA & Cohort & 10803 & Both & $13-18$ & Single-parent, two-parent & $\begin{array}{l}\text { A significant association was found between alcohol use and } \\
\text { living in a single-parent family. }\end{array}$ \\
\hline (76) & USA & Cohort & 4200 & Both & $13-18$ & Intact nuclear family, having an older sibling & $\begin{array}{l}\text { A significant association was found between alcohol use, living } \\
\text { with an intact nuclear family, and having a older sibling. }\end{array}$ \\
\hline$(43)^{\mathbf{a}}$ & Canada & $\begin{array}{c}\text { Cross- } \\
\text { sectional }\end{array}$ & 3564 & Both & $12-24$ & Two parents, one parent, siblings & No significant association was found \\
\hline$(44)^{\mathbf{a}}$ & UK & $\begin{array}{c}\text { Cross- } \\
\text { sectional }\end{array}$ & 3984 & Both & 14-15 & Both biological parents & No significant association was found \\
\hline$(30)^{\mathbf{a}}$ & $\begin{array}{l}\text { France and } \\
\text { United } \\
\text { Kingdom }\end{array}$ & $\begin{array}{c}\text { Cross- } \\
\text { sectional }\end{array}$ & 4925 & Both & $15-16$ & Two parents, single-parent, restructured family & $\begin{array}{l}\text { A significant association was found between alcohol use and } \\
\text { family structure in girls of the UK }\end{array}$ \\
\hline$(37)^{\mathbf{a}}$ & USA & Cohort & 1648 & Both & $11-15$ & $\begin{array}{l}\text { 1-Parents, siblings, grandparents, 2-Mother, father, } \\
\text { siblings, 3-Mother, 4-Mother, grandparents, } \\
\text { 5-Mother, stepfather, 6-Father, 7-Father, } \\
\text { grandparents, 8-Father, stepmother, } \\
\text { 9-Grandparents, and 10-other people }\end{array}$ & $\begin{array}{l}\text { Alcohol use was significantly lower in children living with a } \\
\text { biological family than in children living in a } \\
\text { broken/restructured family }\end{array}$ \\
\hline$(36)^{\mathbf{a}}$ & USA & Cohort & 7188 & Both & $<17$ & $\begin{array}{l}\text { Parental loss, death of parents, non-death } \\
\text { separation }\end{array}$ & $\begin{array}{l}\text { There was a significant association between parental loss and all } \\
\text { forms of separation and increased risk of alcohol use }\end{array}$ \\
\hline (77) & UK & Cohort & 2641 & Both & $15-16$ & Both parents, non-intact & $\begin{array}{l}\text { There was a significant association between alcohol use and } \\
\text { single-parent families }\end{array}$ \\
\hline (70) & $\begin{array}{l}11 \text { European } \\
\text { countries }\end{array}$ & $\begin{array}{c}\text { Cross- } \\
\text { sectional }\end{array}$ & 34001 & Female & $15-16$ & $\begin{array}{l}\text { Both biological parents, single-parent, stepparent, } \\
\text { other (only with a stepparent, foster parent, } \\
\text { grandparent, siblings, other relatives, } \\
\text { non-relatives) }\end{array}$ & $\begin{array}{l}\text { There was a significant association between alcohol use, } \\
\text { especially living with a father, stepmother, and single father. }\end{array}$ \\
\hline (64) & Switzerland & $\begin{array}{c}\text { Cross- } \\
\text { sectional }\end{array}$ & 1488 & Both & $15-16$ & Single-parent, both parents & $\begin{array}{l}\text { There was a significant association between alcohol use and } \\
\text { living with a single parent. }\end{array}$ \\
\hline (71) & Iceland & $\begin{array}{c}\text { Cross- } \\
\text { sectional }\end{array}$ & 3524 & Both & $15-16$ & $\begin{array}{l}\text { Two-parent, mother not in the household, father } \\
\text { not in the home, stepparent }\end{array}$ & $\begin{array}{l}\text { There was a significant association between alcohol use and } \\
\text { living in families where the father was not in the household and } \\
\text { the stepparent. }\end{array}$ \\
\hline (74) & USA & $\begin{array}{c}\text { Cross- } \\
\text { sectional }\end{array}$ & 1027 & Both & $13-18$ & $\begin{array}{l}\text { Biological dad living at home, father-figure living } \\
\text { at home, no father at home. }\end{array}$ & No significant association was found \\
\hline$(45)^{\mathbf{a}}$ & USA & $\begin{array}{c}\text { Cross- } \\
\text { sectional }\end{array}$ & 52278 & Both & $12 \cdot 18$ & $\begin{array}{l}\text { Single-parent, Blended families (stepparent } \\
\text { families and other family arrangements) }\end{array}$ & $\begin{array}{l}\text { There was a significant association between alcohol use and } \\
\text { living with a blended family. }\end{array}$ \\
\hline (73) & USA & $\begin{array}{c}\text { Cross- } \\
\text { sectional }\end{array}$ & 9657 & Both & $12 \cdot 18$ & Single-parent & $\begin{array}{l}\text { There was a significant association between alcohol use and } \\
\text { living with a single father (females who lived with their fathers } \\
\text { were significantly more likely to drink) }\end{array}$ \\
\hline$(38)^{\mathbf{a}}$ & Finland & Cohort & 1132 & Both & Birth - 15 & $\begin{array}{l}\text { Child's separation from one of the parents (before } \\
15 \text { years old), new significant adult in the child's life } \\
\text { (before } 15 \text { years old) }\end{array}$ & $\begin{array}{l}\text { Mother-related variables were associated with child's separation } \\
\text { from one of the parents and alcohol use (before } 15 \text { years old) }\end{array}$ \\
\hline (65) & Switzerland & $\begin{array}{c}\text { Cross- } \\
\text { sectional }\end{array}$ & 3127 & Both & $14-15$ & Two-parent, single-parent, other set-ups & No significant association was found \\
\hline$(84)^{\mathbf{a}}$ & Sweden & $\begin{array}{c}\text { Cross- } \\
\text { sectional }\end{array}$ & 12,582 & Both & 15 & $\begin{array}{l}\text { Two-parent, single-mother, single-father, shared } \\
\text { physical custody. }\end{array}$ & $\begin{array}{l}\text { There was a significant association between alcohol use and } \\
\text { living with single-mother families, single-father families, and } \\
\text { shared physical custody. }\end{array}$ \\
\hline (33) & USA & $\begin{array}{c}\text { Cross- } \\
\text { sectional }\end{array}$ & 97 & Both & $13-19$ & $\begin{array}{l}\text { Two-parent, single-parent, stepparent, other family } \\
\text { members }\end{array}$ & $\begin{array}{l}\text { There was a significant association between alcohol use and } \\
\text { living with a single parent. }\end{array}$ \\
\hline (78) & USA & $\begin{array}{c}\text { Cross- } \\
\text { sectional }\end{array}$ & 1256 & Both & $13-19$ & One-parent, two-parent & $\begin{array}{l}\text { There was a significant association between alcohol use and } \\
\text { living with one parent and two parents. }\end{array}$ \\
\hline (79) & USA & $\begin{array}{c}\text { Cross- } \\
\text { sectional }\end{array}$ & 2138 & Both & $12-14$ & $\begin{array}{l}\text { Both parents, single-mother, mother and } \\
\text { stepfather, mother and other adult, non-relatives } \\
\text { or guardian households }\end{array}$ & No significant association was found \\
\hline (17) & Spain & $\begin{array}{c}\text { Cross- } \\
\text { sectional }\end{array}$ & 386 & Both & $12-17$ & $\begin{array}{l}\text { Nuclear family, single-parent family, extended } \\
\text { family, bi-nuclear family }\end{array}$ & No significant association was found \\
\hline$(46)^{\mathbf{a}}$ & USA & $\begin{array}{c}\text { Cross- } \\
\text { sectional }\end{array}$ & 255 & Both & $14-16$ & $\begin{array}{l}\text { Only mother, only father, older siblings, younger } \\
\text { siblings, grandparents }\end{array}$ & $\begin{array}{l}\text { There was a significant association between alcohol use and } \\
\text { living with older siblings }\end{array}$ \\
\hline
\end{tabular}




\begin{tabular}{|c|c|c|c|c|c|c|c|}
\hline$(47)^{\mathbf{a}}$ & Greece & $\begin{array}{c}\text { Cross- } \\
\text { sectional }\end{array}$ & 500 & Both & $17 \cdot 20$ & $\begin{array}{l}\text { Divorced (single parent), intact family (biological } \\
\text { parent) }\end{array}$ & No significant association was found \\
\hline$(48)^{\mathbf{a}}$ & France & $\begin{array}{c}\text { Cross- } \\
\text { sectional }\end{array}$ & 15000 & Both & $12-18$ & $\begin{array}{l}\text { Intact family, reconstituted family, single-parent } \\
\text { family }\end{array}$ & $\begin{array}{l}\text { There was a significant association between alcohol use and } \\
\text { girls living in an intact family, reconstituted family, and } \\
\text { single-parent family. }\end{array}$ \\
\hline (72) & USA & Cohort & 10704 & Female & $14-16$ & $\begin{array}{l}\text { Biological/adoptive parent, mother-only, } \\
\text { father-only, mother-stepfather, father-stepmother, } \\
\text { dissolution of the parental relationship (divorced) }\end{array}$ & $\begin{array}{l}\text { There was a significant association between alcohol use and } \\
\text { living with mother-only, father-only, mother-stepfather, and } \\
\text { other families. }\end{array}$ \\
\hline$(49)^{\mathbf{a}}$ & USA & $\begin{array}{c}\text { Cross- } \\
\text { sectional }\end{array}$ & 128 & Both & 13-19 & Two-parent, One-parent & $\begin{array}{l}\text { There was a significant association between alcohol use and not } \\
\text { living with biological parents. }\end{array}$ \\
\hline$(50)^{\mathbf{a}}$ & USA & $\begin{array}{c}\text { Cross- } \\
\text { sectional }\end{array}$ & 8795 & Both & $12-16$ & $\begin{array}{l}\text { Two-parent, non-intact families } \\
\text { (father-stepmother, mother-only, father-only, } \\
\text { mother-stepfather) }\end{array}$ & $\begin{array}{l}\text { There was a significant association between alcohol use and } \\
\text { living in two-parent, father-stepmother, or other family } \\
\text { structures. }\end{array}$ \\
\hline$(51)^{\mathbf{a}}$ & Romania & $\begin{array}{c}\text { Cross- } \\
\text { sectional }\end{array}$ & 290 & Both & $14-20$ & Intact, non-intact, reconstructed family & No significant association was found \\
\hline$(18)^{\mathbf{a}}$ & Slovakia & $\begin{array}{c}\text { Cross- } \\
\text { sectional }\end{array}$ & 3694 & Both & $14-15$ & Parental divorce, single, complete family & $\begin{array}{l}\text { There was a significant association between alcohol use and } \\
\text { living with a divorced parent. }\end{array}$ \\
\hline$(39)^{\mathbf{a}}$ & Australia & Cohort & 4158 & Both & $5-14$ & $\begin{array}{l}\text { Married/same partner, single/no partner, one } \\
\text { change of partner, two or more partners }\end{array}$ & $\begin{array}{l}\text { There was a significant association between alcohol use and } \\
\text { living with parents that were married/same partner or } \\
\text { single/no partner, living with parents that had one change of } \\
\text { partner and two or more partners. }\end{array}$ \\
\hline$(52)^{\mathbf{a}}$ & Australia & $\begin{array}{c}\text { Cross- } \\
\text { sectional }\end{array}$ & 8256 & Both & $10-14$ & Two-parent, single mother & $\begin{array}{l}\text { There was a significant association between alcohol use and } \\
\text { living with two parents and a single mother. }\end{array}$ \\
\hline$(31)^{\mathbf{a}}$ & Hong Kong & $\begin{array}{c}\text { Cross- } \\
\text { sectional }\end{array}$ & 32961 & Both & $12-17$ & Intact, non-intact (no-parent, single ) & $\begin{array}{l}\text { There was a significant association between alcohol use and } \\
\text { living with non-intact families. }\end{array}$ \\
\hline (66) & USA & $\begin{array}{c}\text { Cross- } \\
\text { sectional }\end{array}$ & 4173 & Both & $12-18$ & Father-only, mother-only, dual-parent & $\begin{array}{l}\text { There was a significant association between alcohol use and } \\
\text { living with father-only. }\end{array}$ \\
\hline (67) & USA & Cohort & 20745 & Both & $13-18$ & $\begin{array}{l}\text { Both biological parents, one biological parent } \\
\text { (single), stepparents, other }\end{array}$ & $\begin{array}{l}\text { There was a significant association between alcohol use and } \\
\text { living with a single parent. }\end{array}$ \\
\hline (69) & Australia & Cohort & 4281 & Both & $14-18$ & Divorce, siblings & No significant association was found \\
\hline (80) & $\begin{array}{l}\text { Northern } \\
\text { Europe }\end{array}$ & $\begin{array}{c}\text { Cross- } \\
\text { sectional }\end{array}$ & 53053 & Both & $12-18$ & Single-parent, stepparent, both parents & $\begin{array}{l}\text { There was a significant association between alcohol use and } \\
\text { living with an incomplete family. }\end{array}$ \\
\hline (68) & USA & Cohort & 8026 & Both & $12-18$ & $\begin{array}{l}\text { Biological parent, stepparent, non-parent families } \\
\text { (grandparent, an aunt and/or uncle, older siblings, } \\
\text { extended family) }\end{array}$ & $\begin{array}{l}\text { There was a significant association between alcohol use and } \\
\text { living with a single parent. }\end{array}$ \\
\hline (22) & Belgium & $\begin{array}{c}\text { Cross- } \\
\text { sectional }\end{array}$ & 1688 & Both & 11-18 & Both parents, broken family (single, stepparent) & $\begin{array}{l}\text { There was a significant association between alcohol use and } \\
\text { living with stepparent and single-parent }\end{array}$ \\
\hline$(53)^{\mathbf{a}}$ & USA & $\begin{array}{c}\text { Cross- } \\
\text { sectional }\end{array}$ & 14268 & Both & 18 & Both parents, mother alone, father alone, other & $\begin{array}{l}\text { There was a significant association between alcohol use and } \\
\text { living with both parents. }\end{array}$ \\
\hline$(54)^{\mathbf{a}}$ & Hong Kong & $\begin{array}{c}\text { Cross- } \\
\text { sectional }\end{array}$ & 21627 & Both & $11-20$ & Married, divorced, loss of one parent & $\begin{array}{l}\text { There was a significant association between alcohol use and } \\
\text { living with a married parent, divorced parent, and loss of one } \\
\text { parent. }\end{array}$ \\
\hline$(55)^{a}$ & Slovakia & $\begin{array}{c}\text { Cross- } \\
\text { sectional }\end{array}$ & 3882 & Both & $10-16$ & Complete and incomplete family & $\begin{array}{l}\text { There was a significant association between alcohol use and } \\
\text { living with complete and incomplete families. }\end{array}$ \\
\hline (75) & USA & Cohort & 2051 & Both & $12-17$ & $\begin{array}{l}\text { Both biological parents, non-intact(single-parent, } \\
\text { blended: one biological parent and one } \\
\text { stepparent) }\end{array}$ & $\begin{array}{l}\text { There was a significant association between alcohol use and } \\
\text { living with a non-intact family. }\end{array}$ \\
\hline$(56)^{a}$ & USA & $\begin{array}{c}\text { Cross- } \\
\text { sectional }\end{array}$ & 1036 & Both & $15-18$ & Both parents, alternative (other) & No significant association was found \\
\hline (81) & USA & Cohort & 193 & Both & $14-18$ & Nuclear family, both parents & $\begin{array}{l}\text { There was a significant association between alcohol use and } \\
\text { living with both parents. }\end{array}$ \\
\hline$(40)^{\mathbf{a}}$ & USA & Cohort & 931 & Female & $10-15$ & $\begin{array}{l}\text { Divorced only, separated only, both separation and } \\
\text { divorce }\end{array}$ & $\begin{array}{l}\text { There was a significant association between alcohol use and } \\
\text { living with divorced parents and separated parents }\end{array}$ \\
\hline$(57)^{\mathbf{a}}$ & USA & $\begin{array}{c}\text { Cross- } \\
\text { sectional }\end{array}$ & 360 & Both & $12 \cdot 18$ & Both parents, other & No significant association was found \\
\hline$(82)$ & Turkey & $\begin{array}{c}\text { Cross- } \\
\text { sectional }\end{array}$ & 8402 & Both & $12-18$ & Single (separation, loss), both parents & $\begin{array}{l}\text { There was a significant association between alcohol use and } \\
\text { living with a single parent and both parents. }\end{array}$ \\
\hline$(42)^{\mathbf{a}}$ & USA & $\begin{array}{c}\text { Cross- } \\
\text { sectional }\end{array}$ & 193202 & Male & $11-15$ & $\begin{array}{l}\text { Mother-father, mother-father-grandparent, single } \\
\text { mother, single father, mother-stepfather, } \\
\text { father-stepmother, mother-grandparent, } \\
\text { father-grandparent, grandparents only, no parents } \\
\text { or grandparents, joint custody, other family types }\end{array}$ & $\begin{array}{l}\text { There was a significant association between alcohol use and } \\
\text { living with mother-father, mother-father-grandparent, single } \\
\text { mother, single father, mother-stepfather, father-stepmother, } \\
\text { joint custody, and other family types }\end{array}$ \\
\hline
\end{tabular}

a Included in the meta-analysis. 